\title{
Barley competitive ability in coexistence with black oat or wild radish
}

\author{
Habilidade competitiva da cevada em convivência com aveia-preta ou nabo \\ Lisiane Camponogara FONTANA ${ }^{1}$; Carlos Eduardo SCHAEDLER ${ }^{1}$; André da Rosa ULGUIM ${ }^{1}$; \\ Dirceu AGOSTINETTO ${ }^{2}$; Cláudia de OLIVEIRA ${ }^{1}$
}

1 Eng. Agr., aluno do Programa de Pós-Graduação em Fitossanidade; Universidade Federal de Pelotas; Faculdade de
Agronomia Eliseu Maciel; Centro de Herbologia (CEHERB); lisicamponogara@gmail.com,
caduschaedler@yahoo.com.br, andre_ulguim@yahoo.com.br, oliveirac.agro@gmail.com
2 Autor para correspondência (Corresponding author); Eng. Agr., Dr.; Universidade Federal de Pelotas; Faculdade de
Agronomia Eliseu Maciel; Departamento de Fitossanidade, Centro de Herbologia (CEHERB); Campus Universitário,
S/N - CEP.96160-000; Capão do Leão-RS; dirceu.agostinetto@pq.cnpq.br

Recebido em: 25-06-2014; Aceito em: 08-01-2015

\begin{abstract}
The objective of this study was to investigate the relative competitive ability of barley crop with the weed species of black oat or radish. Three experiments were conducted under greenhouse at UFPel in a completely randomized design, with four replications, and treatments arranged in a replacement series. The proportions of barley plants and competitors of black oat or wild radish were: 100:0, 75:25, 50:50, 25:75 and 0:100, always with a total population of 578 and 770 plants $\mathrm{m}^{-2}$ for black oat and wild radish, respectively. The variables evaluated were plant height; leaf area and shoot dry mass. Statistical analysis was performed by applied diagrams to the replacement series and interpretations of competitiveness indices. Barley has superior competitive ability to radish but below the oat. For barley, the interspecific competition with oat is more harmful, while in competition with wild radish has independent if competitor is own crop or weed.
\end{abstract}

Additional keywords: Avena strigosa; Hordeum vulgare; interference; Raphanus sativus.

Resumo

O objetivo deste trabalho foi investigar a habilidade competitiva relativa da cultura da cevada com as espécies daninhas aveia-preta ou nabo. Foram realizados três experimentos em casa de vegetação, em delineamento completamente casualizado, com quatro repetições, sendo os tratamentos arranjados em série de substituição. As proporções de plantas de cevada e dos competidores aveia-preta ou nabo foram: 100:0, 75:25, 50:50, 25:75 e 0:100, com população total de 578 e 770 plantas $\mathrm{m}^{-2}$, para aveia-preta e nabo, respectivamente. As variáveis avaliadas foram estatura, área foliar e massa seca da parte aérea. A análise estatística foi realizada por diagramas aplicados aos experimentos substitutivos com as interpretações dos índices de competitividade. A cevada apresenta habilidade competitiva superior ao nabo, mas inferior à aveia-preta. Para a cevada, a competição interespecífica com aveia-preta é mais prejudicial, enquanto que em competição com nabo independe se o competidor é própria cultura ou a planta daninha.

Palavras-chave adicionais: Avena strigosa; Hordeum vulgare; interferência; Raphanus sativus.

\section{Introduction}

Barley (Hordeum vulgare L.) is a winter cereal that has as its main economic use the production of malt used for beverage production. The world's largest barley producer is Russia, which produced about 14 million tons of the grain in 2012 (FAO, 2014). In Brazil, in the same period, the production was of about 250 thousand tons, with the Southern Region states being responsible for this production, emphasizing Paraná, home of approximately $61 \%$ of national production (IBGE, 2014).

Although barley is reported as one of the crops that have a higher competitive ability in relation to weeds (DHIMA et al., 2010), losses resulting from competition are constantly observed in crop productivity, which can reach $71 \%$ (SCURSONI \&
SATORRE, 2005). Competition is a negative interaction that occurs when individuals require one or more resources that are limited in the medium (RADOSEVICH et al., 1997).

There are several reports of the higher competitive ability of barley with different weeds, with the ryegrass (Lolium multiflorum L.) among them, in the period derived from tillering to the maturation stage (WANIC et al., 2013). The Papaver rhoeas L. and Veronica hederifolia L. biomass was reduced to around 65 and $79 \%$, respectively, due to competition with different barley cultivars and due to the higher competitive ability of the crop (DHIMA et al., 2008). The increase in barley plants population in relation to Chenopodium album L., Stellaria media L., Erysimum cheiranthoides L., Cirsium arvense (L.) Scop. and Equisetum arvense L. weeds provided a 
reduction of their growth, indicating the higher competitive ability of the crop in this situation (PILIPAVICIUS et al., 2011).

The competitive advantage of barley on other species is attributed to its fast initial growth rate, which increases its efficiency in the use of resources in relation to light and nutrients in the soil (MOLLA \& SHARAIHA, 2010). However, the effect of negative interactions between plants is dependent on several factors, among which the species, their morphological and physiological characteristics and the plant population in competition.

Among the main species that infest barley crops there are ryegrass (Lolium multiflorum L.), black oats (Avena strigosa Schreb.) and wild radish (Raphanus sativus L.). However, studies to determine barley competitive ability against these weeds are scarce. It was found that there is ryegrass competition effect on barley crop, showing that this weed has high competitive ability in relation to BRS Greta and BRS 225 cultivars, assessed 50 days after plant emergence (GALON et al., 2011). In a study testing the competitive ability of different barley cultivars, it was observed that the productivity loss due to Avena spp. interference varied from 6 to $79 \%$ (WATSON et al., 2006). Thus, studies aimed to elucidate the competitive interactions between these species and barley are needed.

To determine the competitive interactions between weeds and crops, several methodologies were developed, highlighting replacement series experiments, which allow to study inter and intraspecific competition, with the aim to indicate which species or genotype is more competitive (COUSENS, 1991). The premise of this type of experiment is that association productivity shall be determined in comparison to monocultures. This method of study allows to evaluate the influence of variation in the proportion of species, and not only the plant population in the competitive process.

The hypothesis of this research was that black oat or wild radish weeds have less competitive ability when occurred in equal proportions to barley, under appropriate resources levels. Thus, the objective of the research was to investigate the relative competitive ability of barley crop with black oat or wild radish weeds, using the replacement series method.

\section{Material and methods}

Three experiments were conducted in a greenhouse, from May to September 2008. In all experiments, the experimental design used was complete randomized, with four replications.

The first experiment consisted of barley and black oat monocultures, aiming to determine the population of plants from which the shoot dry weight (SDW) per unit area $\left(\mathrm{g} \mathrm{m}^{-2}\right)$ became independent of the population, according to the "law of constant final yield" (RADOSEVICH et al., 1997). The populations used were of $1,2,4,8,16,24$ and 32 plants pot ${ }^{-1}$ (equivalent to 24, 48, 96, 193, 385, 578 and 770 plants $\mathrm{m}^{-2}$ ).

MN 721 cultivar barley seeds and black oat seeds were used and sown in pots with $8 \mathrm{~L}$ capacity and $23 \mathrm{~cm}$ diameter, filled with Red-Yellow Podzolic sandy loam texture soil, which belong to Pelotas mapping unit (EMBRAPA, 1999). The SDW was evaluated 40 days after emergence (DAE) through plants shoots weighing, after it was dried in an oven with forced air at $60{ }^{\circ} \mathrm{C}$ for 72 hours. Data analysis established that plants population per experimental unit, where the variable has become constant, was of 28 plants for barley and 20 for black oat (data not shown). For wild radish, 36 plants per pot population was considered, as determined in experiments by RIGOLI et al. (2008), once experimental conditions were similar in both studies.

The second and third experiments were conducted in replacement series, and plants populations per pot were originated from the average obtained for the species in the first experiment, resulting in 32 plants per pot for barley and wild radish (Experiment II) and 24 plants for barley and black oats (Experiment III). Treatments consisted of barley and wild radish or black oat plants proportions, depending on the experiment, with the following proportions: 100: 0 (pure barley stand), 75:25, 50:50, 25:75 and 0: 100\% (pure wild radish or black oat stand). All experimental units were identical to those of the first experiment and the seeds were sown in higher populations, to the desired in each treatment, with roughing performed at 7 DAE for surplus plants withdrawal.

The variables evaluated at 40 DAE were height $(\mathrm{H})$, leaf area (LA) and SDW of barley and competing species. Plant height was measured with the help of a millimeter ruler, taking the length from ground level to the apex thereof, with the plant leaves limbo distended. LA was determined with a leaf area meter, LI $3200 \mathrm{C}$ model, with the value obtained in $\mathrm{cm}^{2}$ and converted into $\mathrm{cm}^{2}$ plant ${ }^{-1}$, and SDW was quantitated as described in the first experiment and expressed in $\mathrm{g}_{\text {plant }}{ }^{-1}$.

For data analysis, graphical analysis of the relative yield method was used (COUSENS, 1991; RADOSEVICH, 1987; ROUSH et al., 1989). This procedure consists in the construction of diagrams based on relative (RY) or total (RYT) yields in plants proportions of $0,25,50,75$ and $100 \%$ of the culture and of the competitor, using the average per plant of each species in each experimental unit for calculation. In these diagrams, the results obtained are compared with hypothetical straight line values, which connect points zero and one of the diagram, representing the absence of interference between genotypes. If the $R Y$ result is a concave line, it means that there is a growth loss of one or both species, while if the line shown by RY is convex, there is an 
advantage in growth of one or both species. When the RYT is equal to unity (1) (straight line), it means that there is competition for the same resources; If it is higher than one (convex line), competition is avoided; and when it is lower than one (concave line), it means that antagonism occurs, with mutual damage to the species growth (COUSENS, 1991; RADOSEVICH et al., 2007).

The relative competitiveness indexes $(\mathrm{RCl})$, which represent the comparative growth of the crop (barley) in relation to the competitor species (wild radish or black oat); the relative grouping coefficients $(\mathrm{K})$, which indicates the relative dominance of one species over another; and the aggressivity coefficients $(A)$, which shows the most competitive species were calculated (COUSENS, 1991; COUSENS \& O'NEILL, 1993). The joint interpretation of these values indicates the competitiveness of the species involved with more security. Barley crop is more competitive than the competitor when $\mathrm{RCl}>1, \mathrm{~K}_{\text {barley }}>\mathrm{K}_{\text {competitor }}$ and $\mathrm{A}>0$ (HOFFMAN \& BUHLER, 2002). The competitor species (wild radish or black oat) is more competitive than barley when $\mathrm{RCl}<1, \mathrm{~K}_{\text {barley }}<\mathrm{K}_{\text {competitor }}$ and $\mathrm{A}<0$.

To statistically analyze relative yield, the difference for RY values (RDY) obtained in the plant proportions of 25,50 and $75 \%$ was calculated in relation to the hypothetical straight line values obtained in the respective proportions (BIANCHI et al. 2006; PASSINI, 2001). Then the "t" test ( $p \leq 0.05)$ was used to test differences in RDY, RYT, RCI, $\mathrm{K}$ and A indexes (HOFFMAN \& BUHLER, 2002; ROUSH et al., 1989). The null hypothesis to test RDY and $A$ differences are that means are equal tozero $\left(\mathrm{H}_{0}=0\right)$; for RYT and $\mathrm{RCl}$, that the means are equal to one $\left(\mathrm{H}_{0}=1\right)$; for the $\mathrm{K}$ index, in which the differences means between $\mathrm{K}$ barley and $\mathrm{K}_{\text {competitor }}$ are equal to zero, $\left[\mathrm{H}_{0}=\left(\mathrm{K}_{\text {barley }}-\mathrm{K}_{\text {competitor }}\right)=0\right]$. The criteria to consider the RY and RYT curves different from the hypothetical straight lines and the existence of differences in competitiveness for $\mathrm{RCl}, \mathrm{K}$ and $\mathrm{A}$ indexes was that, in at least two proportions, differences occur by "t" test (BIANCHI et al., 2006).

The results obtained for plants $H, L A$ and SDW, expressed as average values per plant, were subjected to analysis of variance. When the $F$ test indicated significance ( $p \leq 0.05)$, the treatment means were compared by Dunnett's test ( $p \leq 0.05)$, considering its respective monocultures as witnesses.

\section{Results and discussions}

By analyzing the RY of barley and wild radish competitors, close results to the hypothetical line were observed for the $\mathrm{H}$ variable (Figure 1). For LA and SDW variables, a line close to the straight line for barley and concave for wild radish was found, indicating that for barley, in general, the competitor presence did not represent losses, while the wild radish was less competitive. Similarly, barley was considered more competitive than pea (Pisum sativum L.) by nitrogen due to a deeper root system and for the rapid initial demand of the nutrient (CORRE-HELLOU et al., 2007).

For barley and black oat combination, RY close to the hypothetical line was found for the $\mathrm{H}$ variable, while for $L A$ and SDW variables concave lines were found for the culture, and a convex line was found for the competitor to LA and a line next to the hypothetical straight line was found for the competitor SDW, indicating that barley is less competitive (Figure 1). In a study evaluating the ryegrass competition with barley, there were concave lines for the $R Y$ regarding tillers number, LA and SDW variables, indicating the occurrence of competition for the same environmental resources, with mutual adverse effects on growth of both culture and competitor (GALON et al., 2011).

There are reports of barley competitive advantage on the ryegrass, resulting in a high rate of initial growth, better root development in the early development stages and high LA (WANIC et al., 2013). Similarly, in competition with Medicago scutellata L., barley showed no prejudice by increasing the weed population, and this showed lower RY when present in a smaller proportion in the mixture (SADEGHPOURA et al., 2013). The results obtained of this study, in which black oat plants competed more intensely by the resources than wild radish plants when in competition with the barley crop, can be explained by the fact that there is greater phenotypic similarity between black oat and culture plants, evidenced by the fact that these species belong to the same botanical family.

Adopting the occurrence of differences in at least two indices as the criterion to establish the difference between estimated and hypothetical lines (BIANCHI et al., 2006), differences for LA and SDW variables were found for barley when the culture was in competition with black oats (Table 1). For the black oat, there was no difference for the variables, while the wild radish was different only for the SDW variable.

The RYTs for $\mathrm{H}$ and LA variables, in general, showed values close to one, with no differences, while values lower than unity were observed for SDW, with difference found for barley and black oats competition (Figure 1 and Table 1). These results demonstrate that there is mutual impairment of species growth, i.e., species compete for the same niche. However, this result is different depending on the species studied, as it was observed that the RYT of barley and Medicago scutellata L. combination was higher than the hypothetical value, indicating advantages for both species (SADEGHPOURA et al., 2013).

In mixed populations, ryegrass captured more effectively the available resources than barley from stem elongation period to the end of the growing season (WANIC et al., 2013). 
Height

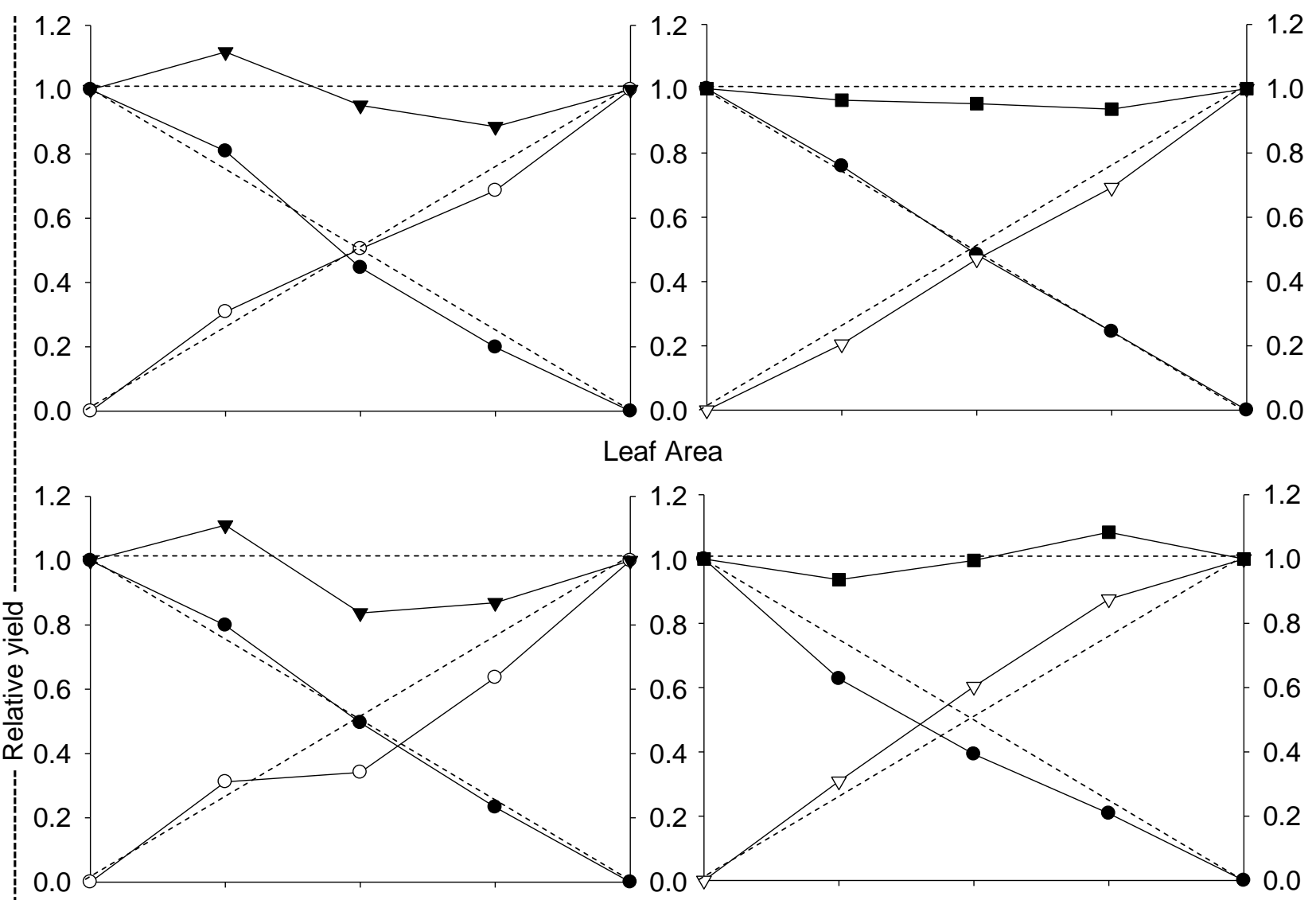

Dry mass of shoots

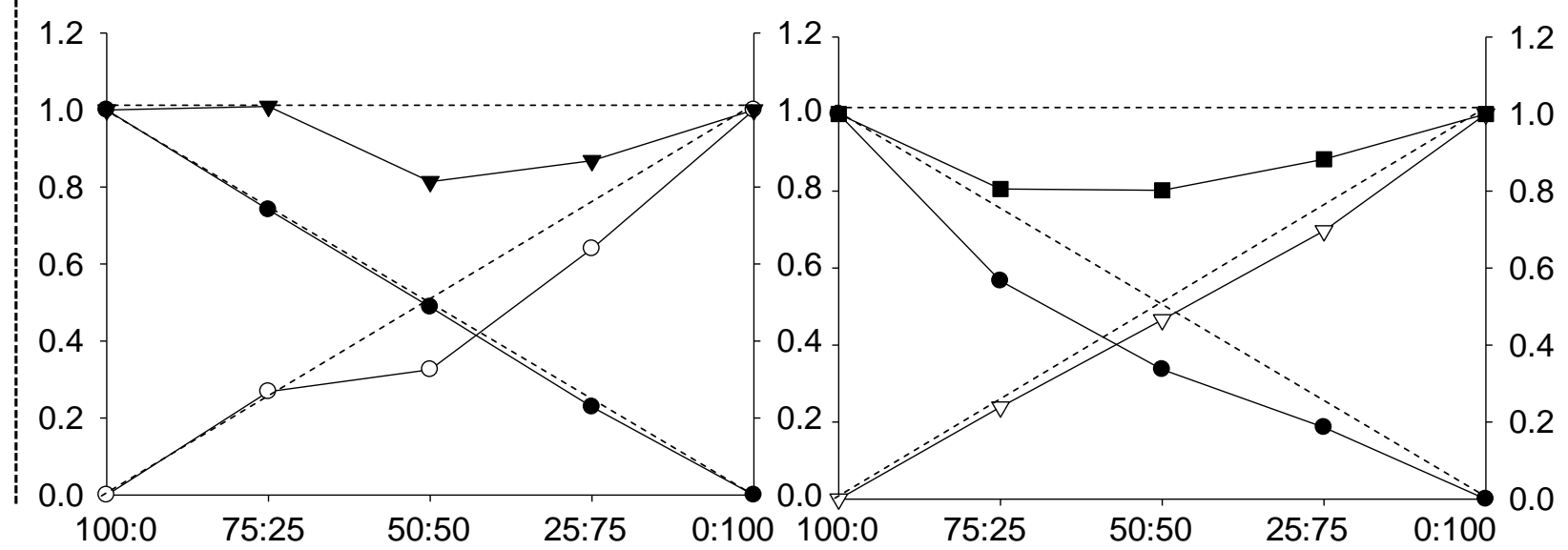

Barley:Wild radish plant proportion (\%)

Barley:Black oat plant proportion (\%)

Figure 1 - Relative yield of barley $(\bullet)$, wild radish $(\bigcirc)$ and black oat $(\nabla)$, and relative yield total ( $\nabla$ for combination with wild radish and $\mathbf{m}$ the combination with black oat) for the variables height, leaf area and dry mass of shoots, depending on the ratio between the species in plant population. The dashed lines refer to the hypothetical relative yields.

In a study evaluating the competition between barley and ryegrass in replacement series, it was found, in general, differences in all plant proportions (GALON et al., 2011). Other studies also denoted differences in competitive ability between closely related species, such as rice and barnyardgrass, (AGOSTINETTO et al., 2008), wheat and ryegrass (RIGOLI et al., 2008) and between sor- ghum and Johnson grass or between sorghum and a wild sorghum biotype originated from the cultivated sorghum (HOFFMAN \& BUHLER, 2002). Losses derived from competition depend primarily on the species, population, distribution and emergence flows from existing weeds in the area (PARKER \& MURDOCH, 1996). 
Table 1 - Relative differences in yield (RDY) for the variables height, leaf area, dry matter of shoot and total relative yield (RYT), in the proportions 75:25, 50:50 and 25:75 of barley associated with wild radish or black oat.

\begin{tabular}{|c|c|c|c|c|}
\hline \multirow{2}{*}{ Experiments } & & \multicolumn{3}{|c|}{ Plants proportions (barley: competitor) } \\
\hline & & $75: 25$ & $50: 50$ & $25: 75$ \\
\hline \multicolumn{5}{|c|}{ Height } \\
\hline \multirow{3}{*}{ Experiment II } & RDY barley & $0.06( \pm 0.03)^{n=5}$ & $-0.05( \pm 0.03)^{n-5}$ & $-0.05( \pm 0.01)^{\star}$ \\
\hline & RDY wild radish & $0.06( \pm 0.01)^{*}$ & $0.00( \pm 0.04)^{\mathrm{ns}}$ & $-0.06( \pm 0.02)^{n s}$ \\
\hline & RYT & $1.12( \pm 0.04)^{\mathrm{ns}}$ & $0.95( \pm 0.06)^{\text {ns }}$ & $0.88( \pm 0.03)^{*}$ \\
\hline \multirow{3}{*}{ Experiment III } & RDY barley & $0.01( \pm 0.01)^{\mathrm{ns}}$ & $-0.02( \pm 0.03)^{\mathrm{ns}}$ & $-0.01( \pm 0.01)^{\mathrm{ns}}$ \\
\hline & RDY black oat & $-0.05( \pm 0.02)^{\mathrm{ns}}$ & $-0.03( \pm 0.01)^{\mathrm{ns}}$ & $-0.06( \pm 0.02)^{\mathrm{ns}}$ \\
\hline & $\mathrm{RYT}$ & $0.96( \pm 0.03)^{\mathrm{ns}}$ & $0.95( \pm 0.04)^{\text {ns }}$ & $0.94( \pm 0.03)^{\mathrm{ns}}$ \\
\hline \multicolumn{5}{|c|}{ Leaf area } \\
\hline \multirow{3}{*}{ Experiment II } & RDY barley & $0.05( \pm 0.05)^{\mathrm{n} s}$ & $0.00( \pm 0.04)^{n-15}$ & $-0.02( \pm 0.01)^{n}$ \\
\hline & RDY wild radish & $0.06( \pm 0.02)^{\text {ns }}$ & $-0.16( \pm 0.05)^{\star}$ & $-0.11( \pm 0.04)^{n s}$ \\
\hline & RYT & $1.11( \pm 0.05)^{\mathrm{ns}}$ & $0.84( \pm 0.08)^{\text {ns }}$ & $0.87( \pm 0.04)^{*}$ \\
\hline \multirow{3}{*}{ Experiment III } & RDY barley & $-0.12( \pm 0.03)^{*}$ & $-0.11( \pm 0.03)^{*}$ & $-0.04( \pm 0.02)^{\mathrm{ns}}$ \\
\hline & RDY black oat & $0.06( \pm 0.06)^{\mathrm{ns}}$ & $0.10( \pm 0.05)^{\mathrm{ns}}$ & $0.12( \pm 0.03)^{\star}$ \\
\hline & RYT & $0.94( \pm 0.05)^{\mathrm{ns}}$ & $1.00( \pm 0.06)^{\mathrm{ns}}$ & $1.08( \pm 0.03)^{\text {ns }}$ \\
\hline \multicolumn{5}{|c|}{ Dry matter of shoot } \\
\hline \multirow{3}{*}{ Experiment II } & RDY barley & $-0.01( \pm 0.04)^{\mathrm{ns}}$ & $-0.01( \pm 0.03)^{\mathrm{n} s}$ & $-0.02( \pm 0.02)^{\mathrm{ns}}$ \\
\hline & RDY wild radish & $0.02( \pm 0.02)^{\mathrm{ns}}$ & $-0.17( \pm 0.04)^{*}$ & $-0.11( \pm 0.03)^{*}$ \\
\hline & $\mathrm{RYT}$ & $1.01( \pm 0.06)^{\mathrm{ns}}$ & $0.81( \pm 0.07)^{\mathrm{ns}}$ & $0.87( \pm 0.02)^{*}$ \\
\hline \multirow{3}{*}{ Experiment III } & RDY barley & $-0.18( \pm 0.03)^{*}$ & $-0.16( \pm 0.03)^{*}$ & $-0.06( \pm 0.02)^{*}$ \\
\hline & RDY black oat & $-0.01( \pm 0.02)^{\mathrm{ns}}$ & $-0.03( \pm 0.04)^{\mathrm{ns}}$ & $-0.05( \pm 0.02)^{\mathrm{ns}}$ \\
\hline & RYT & $0.81( \pm 0.02)^{*}$ & $0.80( \pm 0.06)^{*}$ & $0.88( \pm 0.02)^{*}$ \\
\hline
\end{tabular}

Considering that a genotype is more competitive than another when $\mathrm{RCl}>1, \mathrm{~K}_{\mathrm{x}}>\mathrm{K}_{\mathrm{y}}$ and A> 0 (HOFFMAN \& BUHLER, 2002) and adopting the occurrence of significant differences in at least two indices as criteria to establish competitive superiority (BIANCHI et al., 2006), it was found that barley crop was more competitive than the wild radish competitor for LA and SDW variables (Table 2). Studies with wild radish showed that this species had a higher relative competitiveness than soybean genotypes (BIANCHI et al., 2006). In wheat competing against ryegrass or wild radish, it was found that wheat had a higher competitive ability compared to ryegrass than for wild radish, when the species occurred in similar plant proportions (RIGOLI et al., 2008). Still, for barley culture cultivation, $\mathrm{RCl}$ and $\mathrm{A}$ values indicated that it is more competitive than the Medicago scutellata $\mathrm{L}$. competitor (SADEGHPOURA et al., 2013), as observed for wild radish in this study.

Regarding the black oat competitor, it was found that it was more competitive than barley for LA variable (Table 2). This result confirms that barley culture showed greater ability to extract resources from the medium when in competition with the wild radish comparing to the black oat, unlike what was observed for other crops, where the wild radish showed greater competitiveness.

Regarding the morphological alterations resulting from competition, when the competitors participated in the smallest proportion (75:25), there was a differentiation between them in the $\mathrm{H}$ variable: the wild radish showed an increase and the black oat a decrease in plants $\mathrm{H}$ when compared to monoculture (Table 3). On the other hand, barley decreased in proportion to this variable only when in a $25: 75$ proportion and in competition against wild radish. For barley in competition with ryegrass, there was an increase of the variable with the increase in the proportion of competitor plants, due to the fact that increased competition between barley and weed stimulate stems to lengthen for light (GALON et al., 2011). Competitive barley cultivars have early stem elongation, with the length of the first two internodes and ofthe main stem being important morphological characteristics that favor the culture incondition and competition (DIDON, 2002).

The coexistence of barley culture with wild radish did not differ in any plants proportion for the LA variable; however, wild radish reduced the variable on 50:50 proportion (Table 3). The LA and SDW of barley cultivars were reduced when in competition against ryegrass in all proportions of replacement series, and the higher the competitor proportion in association with the cultivars, higher was the damage to the culture variables (GALON et al ., 2011).

For the SDW variable, barley culture did not show any differences in proportion when competing with wild radish, which in turn was reduced in the 50:50 proportion (Table 3). On the other hand, when in competition with black oat, the culture decreased in all proportions tested in comparison with monoculture. 
Table 2 - Competitiveness indices between barley and competitors (wild radish or black oat), expressed by relative competitiveness $(\mathrm{RCl})$ and clustering coefficients $(\mathrm{K})$ and aggressivity $(\mathrm{A})$.

\begin{tabular}{|c|c|c|c|c|}
\hline Variables & $\mathrm{RCl}$ & $\mathrm{K}_{\text {barley }}$ & $\mathrm{K}_{\text {competitor }}$ & A \\
\hline \multicolumn{5}{|c|}{ Experiment II - Barley x Wild radish } \\
\hline Height & $0.89( \pm 0.04)^{\mathrm{ns}}$ & $0.82( \pm 0.10)^{\mathrm{ns}^{-1}}$ & $1.05( \pm 0.15)$ & $-0.06( \pm 0.02)^{\mathrm{n} s}$ \\
\hline Leaf area & $1.51( \pm 0.16)^{\mathrm{ns}}$ & $1.02( \pm 0.17)^{\star}$ & $0.54( \pm 0.11)$ & $0.15( \pm 0.03)^{\star}$ \\
\hline Dry matter of shoot & $1.53( \pm 0.11)^{*}$ & $0.98( \pm 0.15)^{*}$ & $0.49( \pm 0.09)$ & $0.16( \pm 0.02)^{*}$ \\
\hline \multicolumn{5}{|c|}{ Experiment III - Barley x Black oat } \\
\hline Hēight & $1.03( \pm 0.03)^{\mathrm{n} s}$ & $0.95( \pm 0.11)^{\mathrm{ns}}$ & $0.89( \pm 0.05)$ & $0,01( \pm 0.02)^{\mathrm{ns}}$ \\
\hline Leaf Area & $0.66( \pm 0.07)^{\star}$ & $0.65( \pm 0.08)^{*}$ & $1.62( \pm 0.28)$ & $-0,21( \pm 0.05)^{*}$ \\
\hline Dry matter of shoot & $0.74( \pm 0.09)^{\mathrm{ns}}$ & $0.51( \pm 0.07)^{\mathrm{ns}}$ & $0.90( \pm 0.13)$ & $-0,13( \pm 0.05)^{\mathrm{ns}}$ \\
\hline
\end{tabular}

${ }^{\text {ns }}$ Not significant through "t" test $(p \leq 0.05)$. Values in parenthesis represent means standard error.

Table 3 - Response of barley to competitor's interference (wild radish or black oat), at 40 days after emergence.

\begin{tabular}{|c|c|c|c|c|c|c|}
\hline \multirow{2}{*}{ Interference } & \multicolumn{6}{|c|}{ Plant proportions (Barley:competitor) } \\
\hline & 100:0 (W) & $75: 25$ & $50: 50$ & $25: 75$ & $0: 100(\mathrm{~W})$ & C.V. (\%) \\
\hline \multicolumn{7}{|c|}{ Height (cm) } \\
\hline \multirow{2}{*}{ Experiment II - ba } & 25.9 & $27.9^{\text {ns }}$ & $23.1^{\text {ns }}$ & $20.6^{*}$ & - & 8.61 \\
\hline & - & $16.9^{*}$ & $13.9^{\text {ns }}$ & $12.5^{\mathrm{ns}}$ & 13.7 & 9.85 \\
\hline \multirow{2}{*}{$\begin{aligned} \text { Experiment III } & \text { - barley } \\
& \text { - black oat }\end{aligned}$} & 24.1 & $24.4^{\mathrm{ns}}$ & $23.3^{\text {ns }}$ & $23.5^{\mathrm{ns}}$ & - & 9.66 \\
\hline & 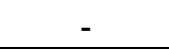 & $25.9^{*}$ & $29.7^{\text {ns }}$ & $29.2^{\text {ns }}$ & 31.6 & 8.93 \\
\hline \multicolumn{7}{|c|}{ Leaf area $\left(\mathrm{cm}^{2}\right.$ plant $\left.{ }^{-1}\right)$} \\
\hline \multirow{2}{*}{$\begin{aligned} \text { Experiment II } & \text { - barley } \\
& \text { - wild radish }\end{aligned}$} & 27.4 & $29.2^{\text {ns }}$ & $27.2^{\text {ns }}$ & $25.5^{\text {ns }}$ & - & 11.76 \\
\hline & - & $32.6^{\text {ns }}$ & $17.9^{*}$ & $22.2^{\text {ns }}$ & 26.2 & 15.25 \\
\hline \multirow{2}{*}{$\begin{aligned} & \text { Experiment III } \text { - barley } \\
& \text { - black oat } \\
&\end{aligned}$} & 30.9 & $25.9^{\text {ns }}$ & $24.3^{\text {ns }}$ & $25.8^{\mathrm{ns}}$ & - & 12.41 \\
\hline & - & $35.8^{\text {ns }}$ & $35.0^{\text {ns }}$ & $33.8^{\text {ns }}$ & 29.0 & 15.05 \\
\hline \multicolumn{7}{|c|}{ Dry matter of shoot (g plant ${ }^{-1}$ ) } \\
\hline \multirow{2}{*}{$\begin{aligned} \text { Experiment II } & \text { - barley } \\
& \text { - wild radish }\end{aligned}$} & 0.18 & $1.18^{\text {ns }}$ & $0.17^{\text {ns }}$ & $0.16^{\text {ns }}$ & - & 14.16 \\
\hline & 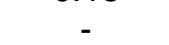 & $0.19^{\text {ns }}$ & $0.14^{*}$ & $0.23^{\text {ns }}$ & 0.22 & 15.10 \\
\hline \multirow{2}{*}{$\begin{aligned} & \text { Experiment III } \text { - barley } \\
& \text { - black oat } \\
&\end{aligned}$} & 0.18 & $0.14^{*}$ & $0.12^{*}$ & $0.14^{*}$ & - & 13.02 \\
\hline & - & $0.15^{\mathrm{ns}}$ & $0.15^{\mathrm{ns}}$ & $0.15^{\mathrm{ns}}$ & 0.16 & 13.81 \\
\hline
\end{tabular}

${ }^{n s}$ Not significant and * significant in relation to the witness (W) through Dunnett's test $(p \leq 0,05)$.

Considering the three analyzed variables, if was found that for a culture competing with wild radish, in general, there is no difference compared to the control (monoculture) (Table 3). However, when in competition with the black oat, for the SDW variable, interspecific competition was more damaging to the culture. For wild radish and black oat weeds, in general, the competitor does not matter, whether is it culture or the weed. The intraspecific competition was considered more important to barley culture in competition with weeds, evidenced by the growing number of culture unproductive stems (PILIPAVICIUS et al., 2011).

Generally, the crop is more competitive than its competitors because the effect of the competitors is not only about the best single competitive ability, but mainly to the total plant population (VILÀ et al., 2004). In such cases, it is common to see field situations in which competitors are presented in extremely higher proportions than culture, causing severe damage to productivity and justifying control measures.

In a study of rice cultivation, it was observed that the LA was the characteristic that was more associated with competitiveness, comparing to plant height (FISCHER et al., 1997). In this study, the SDW was considered the variable indicated to express the competitive ability among the studied species, verifying that in competition with wild radish, barley exceled, causing damage to the weed, while in the combination with the black oat, barley was hampered by competition.

The results allow to infer that in a situation of equivalent infestation of black oats and wild radishes in the cultivation area, there is the need for more attention to black oat control, using herbicides that present efficiency over poaceae. However, it should be noted that the wild radish can cause yield losses of around $70 \%$, as observed for wheat crop when in absence of weed control (AGOSTINETTO et al., 2008). Therefore, it is necessary that the premises of the integrated weed management are observed on barley culture upon the occurrence of these weeds, otherwise, there are significant risks of damaging final production.

\section{Conclusions}

Barley has superior competitive ability against wild radish, but inferior to the black oat. 
For barley, the interspecific competition against the black oat is more harmful, while in competition with the wild radish it does not matter if the competitor is the crop or the weed.

\section{References}

AGOSTINETTO, D.; RIGOLI, R. P.; SCHAEDLER, C. E.; TIRONI, S. P.; SANTOS, L. S. Período crítico de competição de plantas daninhas com a cultura do trigo. Planta Daninha, Campinas, v.26, n.2, p.271278, 2008.

BIANCHI, M. A.; FLECK, N. G.; LAMEGO, F. P. Proporção entre plantas de soja e plantas competidoras e as relações de interferência mútua. Ciência Rural, Santa Maria, v.36, n.5, p.1380-1387, 2006.

CORRE-HELLOU, G.; BRISSON, N.; LAUNAY, M.; FUSTEC, J.; CROZAT, Y. Effect of root depth penetration on soil nitrogen competitive interactions and dry matter production in pea-barley intercrops given different soil nitrogen supplies. Field Crop Research, Amsterdam, v.103, n.1, p.76-85, 2007.

COUSENS, R. Aspects of the design and interpretation of competition (interference) experiments. Weed Technology, Champaign, v.5, n.3, p.664-673, 1991.

COUSENS, R.; O'NEILL, M. Density dependence of replacement series experiments. Oikos, v.66, Copenhagen, n.2, p.347-352, 1993.

DIDON, U. Variation between barley cultivars in early response to weed competition. Journal of Agronomy and Crop Science, Berlin, v.188, n.3, p.176-184, 2002.

DHIMA, K.; VASILAKOGLOU, I.; GATSIS, T.; ELEFTHEROHORINOS, I. Competitive interactions of fifty barley cultivars with Avena sterilis and Asperugo procumbens. Field Crops Research, Amsterdam, v.117, n.1, p.90-100, 2010.

DHIMA, K.; VASILAKOGLOU, I.; LITHOURGIDIS, A.; MECOLARI, E.; KECO, R.; AGOLLI, X. H.; ELEFTHEROHORINOS, I. Phytotoxicity of 10 winter barley varieties and their competitive ability against common poppy and ivy-leaved speedwell. Experimental Agriculture, Cambridge, v.44, n.3, p.385-397, 2008.

EMBRAPA - Empresa brasileira de pesquisa agropecuária. Centro Nacional de Pesquisa de Solos. Sistema brasileiro de classificação de solos. Brasília: 1999. 412p.

FAO. Food and Agriculture Organization of the United Nations. Disponível em $<$ http://faostat3.fao.org/faostatgateway/go/to/browse/Q/QC/E>. Acesso em: 22 jan. 2014.
FISCHER, R. A.; RAMIREZ, H. V.; LOZANO, J. Suppression of junglerice [Echinochloa colona (L.) Link] by irrigated rice cultivars in Latin America. Agronomy Journal, Madison, v.89, n.3, p.516-521, 1997.

GALON, L.; TIRONI, S. P.; ROCHA, P. R. R.; CONCENÇO, G.; SILVA, A. F.; VARGAS, L.; SILVA, A. A.; FERREIRA, E. A.; MINELLA, E.; SOARES, E. R.; FERREIRA, F. A. Habilidade competitiva de cultivares de cevada convivendo com azevém. Planta Daninha, Viçosa, v.29, n.4, p.771-781, 2011.

HOFFMAN, M. L.; BUHLER, D. D. Utilizing Sorghum as functional model of crop-weed competition. I. Establishing a competitive hierarchy. Weed Science, Lawrence, v.50, n.4, p.466-472, 2002.

IBGE. Instituto Brasileiro de Geografia e Estatística. Disponível em

<http://www.ibge.gov.br/home/estatistica/indicadores/agropecuaria/lspa/defaulttab.shtm>. Acesso em: 22 jan. 2014.

MOLLA, A.; SHARAIHA, K. Competition and resource utilization in mixed cropping of barley and durum wheat under different moisture stress levels. The World Journal of Agricultural Sciences, Cambridge, v.6, n.6, p.713-719, 2010.

PARKER, L.; MURDOCH, A. J. Mathematical modeling of multispecies weed competition in spring wheat. In: INTERNATIONAL WEED CONTROL CONGRESS, 2.; 1996. Copenhagen. Proceedings... p.153-158.

PASSINI, T. Competitividade e predição de perdas de rendimento da cultura de feijão quando em convivência com Brachiaria plantaginea (Link) Hitchc. 2001. 130f. Tese (Doutorado em Agronomia) - Escola Superior de Agricultura Luiz de Queiroz, Universidade de São Paulo, Piracicaba, 2001.

PILIPAVICIUS, $\quad$ V.; ROMANECKIENE, R.; ROMANECKAS, K. Crop stand density enhances competitive ability of spring barley (Hordeum vulgare L.). Acta Agriculturae Scandinavica, Stockholm, v.61, n.7, p.648-660, 2011.

RADOSEVICH, S. R. Methods to study interactions among crops and weeds. Weed Technology, Champaign, v.1, n.3, p.190-198, 1987.

RADOSEVICH, S. R.; HOLT, J. S.; GHERSA, C. M. Ecology of weeds and invasive plants: relationship to agriculture and natural resource management. 3.ed. Hoboken: Wiley, 2007. 454p.

RADOSEVICH, S.; HOLT, J.; GHERSA, C. Weed ecology: implications for vegetation management. 2.ed. New York: Wiley, 1997. 589p. 
RIGOLI, R. P.; AGOSTINETTO, D.; SCHAEDLER, C. E.; DAL MAGRO, T.; TIRONI, S. Habilidade competitiva do trigo (Triticum aestivum) em convivência com azevém (Lolium multiflorum) ou nabo (Raphanus raphanistrum). Planta Daninha, v.26, n.1, p.93-100, 2008.

ROUSH, M. L.; RADOSEVICH, S. R.; WAGNER, R. G.; MAXWELL, B. D.; PETERSEN, T. D. A comparison of methods for measuring effects of density and proportion in plant competition experiments. Weed Science, Lawrence, v.37, n.2, p.268-275, 1989.

SADEGHPOURA, A.; JAHANZADA, E.; ESMAEILIB, A.; HOSSEINIB, M.B.; HASHEMIA, M. Forage yield, quality and economic benefit of intercropped barley and annual medic in semi-arid conditions: Additive series. Field Crops Research, Amsterdam, v.148, n.1, p.43-48, 2013.

SCURSONI, J. A.; SATORRE, E. H. Barley (Hordeum vulgare) and wild oat (Avena fatua) competition is affected by crop and weed density. Weed Technology, Lawrence, v.19, n.4, p.790-795, 2005.
VILÀ, M.; WILLIAMSON, M.; LONSDALE, M. Competition experiments on alien weeds with crops: lessons for measuring plant invasion impact? Biological Invasions, Dordrecht, v.6, n.1, p.59-69, 2004.

WANIC, M.; JASTRZĘBSKA, M.; KOSTRZEWSKA, M. K.; TREDER, K. Competition between spring barley (Hordeum vulgare L.) and italian ryegrass (Lolium multiflorum Lam.) under different water supply conditions. Acta Agrobotanica, Warszawa, v.66, n.3, p.73-80, 2013.

WATSON, P. R.; DERKSEN, D. A.; VAN ACKER, R. C.The ability of 29 barley cultivars to compete and withstand competition. Weed Science, Laurence, v.54, n.4, p.783-792, 2006. 